Гуларян А.Б.

\title{
«Грядущая война» как жанр литературы
}

Аннотация: Одним из важнейших показателей готовности общества к новой войне является появление сценариев грядущей войны в литературе. Сценарии «военно-утопических романов» нередко становились прологом действительных событий, «угадывали» характер и контуры будущих сражений. Ведь они отражали эпоху и господствующие в обществе общественные настроения. Не прошли мимо темы грядущей войны и отечественные писатели фантасты. В России жанр «военно-утопического романа» последовательно становился средством выражения своих идей для отставных и действующих военных, средством конструирования желаемого будущего и его пропаганды для революционно настроенной интеллигенции, средством мобилизации общественного сознания для коммунистического руководства страны в предвоенный период. Сюжеты литературных произведений свидетельствуют также о том, что сталинское руководство по-прежнему готовилось к революционно-классовой войне. Жанр сценария грядущих войн выполняет в обществе две социально значимые функции: предупреждения о надвигающейся войне и мобилизации общественного сознания в предвоенный период.

Review: One of the most important signs indicating that a society is ready for a new war is the appearance of war scenarios in literature. Indeed, so called 'utopian war novels' often preceded actual military actions and even predicted the nature and outlines of future battles for these novels reflected the epoch and the public opinion of the epoch. Russian science fiction writers wrote about the coming war, too. In Russia the genre of the utopian war novel has become the mean of expression for former and acting military officers, the mean of building a desired future and propaganda for revolutionary-minded intelligentsia as well as the mean of mobilization of the public spirit for the communist government of the country in the pre-war period. Literary plots of those times also demonstrate that Stalin and his government were still getting ready for the revolutionary war between social classes. The 'coming war' literary genre had the two socially important functions, to warn about the coming war and to mobilize the public spirit in the pre-war period.

Ключевые слова: грядущая война, военно-утопический роман, прогностические возможности, мобилизация общественного сознания, литература, фантастика, писатели, сценарий, роман, сюжетные ходы.

Keywords: coming war, utopian war novel, predictive capabilities, mobilization of the public spirit, literature, science fiction, writers, scenario, novel, plot devices.

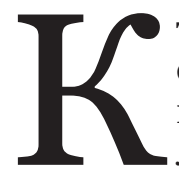

теме грядущей войны в отечественной литературе уже обращались различные исследователи - писатели, ученые, журналисты. Из писателей к этой теме обращался Г. М. Прашкевич, написавший очерки «Гибель шахмат» и «Адское пламя» (вышли двумя изданиями - а 2003 и 2007 гг. $)^{1}$. Из ученых - историк Н. Ю. Кулешова, опубликовавшая в журнале «Отечественная история» в 2002 г. статью ««Большой день»: грядущие войны

\footnotetext{
${ }^{1}$ Прашкевич Г.М. Шпион в Юрском периоде: Сб / Г.Прашкевич, - М.: АСТ, 2003. - С.517-608.; Его же: Адское пламя. Новосибирск, Свиньин и сыновья, 2007. - 196 с.
}

в литературе 1930-х годов» ${ }^{2}$. Из литературных критиков - Е. В. Харитонова с небольшой, но очень ёмкой статьей «Без войны они скучают», которая существует в электронном виде на сайте общественно-политической газеты «Киевский телеграф» и в блоге LitForum ${ }^{3}$. Отдельно следует отметить послесловие

\footnotetext{
2 Кулешова Н.Ю. «Большой день»: грядущая война в литературе 1930-х годов // Отечественная история. -2002. № 1. - С.181-191.

3 Харитонов E.B. «Без войны они скучают»// http://telegrafua.com/world/11848/print/\$ Харитонов Е. Взгляд на фантастику // http://litforum. ru/lofiversion/index.php/t24348.html (последнее посещение - 25 марта 2012 г.)
} 
В. Гончарова «Между Сциллой и Харибдой (Военные альтернативы и альтернативные войны)» к известному роману С.В.Анисимова «Вариант «Бис»» ${ }^{4}$.

Все перечисленные работы в той или иной степени использовались при подготовки настоящей статьи.

$$
* * *
$$

В отечественной литературе сценарии грядущих войн зарождаются и развивается в рамках жанра фантастики, и вместе с указанным жанром претерпевают все изменения. Историю этого поджанра фантастической литературы можно условно разделить на пять этапов: дореволюционные сценарии грядущих войн, сценарии 1920-х гг., сценарии 30-х - начала 40-х гг., бесценарный период (середина 40-х - середина 80-х гг.), современный период - 90-е гг. XX - 10-е гг. XXI в. К сожалению, в рамках одной статьи полностью осветить все этапы развития сценарности грядущей войны просто невозможно.

Следует отметить, что до Первой Мировой войны сочинение сценариев будущей войны было делом почтенным и уважаемым, особенно для отставных военных (но и действующих тоже), ибо, по меткому определению В.Гончарова: «большинство упомянутых произведений рассматривалось в первую очередь как разновидность военно-теоретической, а не художественной литературы» 5. Примером подобного рода литературы могут служить очерки В. В. Крестовского «Наша будущая война» 6 и Е. В. Ларионова «По поводу одного острова (Гадания о будущем)» 7 , романы А. Е. Канкревича «Крейсер «Русская

\footnotetext{
${ }^{4}$ Гончаров В. Между Сциллой и Харибдой // В кн.: Анисимов С.В. Вариант «Бис». - М.: АСТ, Ермак, $2003-544 \mathrm{c}$

${ }^{5}$ Гончаров В. Между Сциллой и Харибдой // В кн.: Анисимов С.В. Вариант «Бис». С.523.

${ }^{6}$ Крестовский В.В. Наша будущая война // Исторический вестник. Историко-литературный журнал. Т.8. С-Пб, Тип. А.С.Суворина, 1882. С.157-167. 7 Ларионов E.B. По поводу одного острова (Гадание о будущем) // Исторический вестник. Историко-литературный журнал. Т.9. С-Пб, Тип. А.С.Суворина, 1882 C.129-163.
}

надежда»» 8 и «Роковая война 18 ?? года» ${ }^{9}$, а также работа адмирала С. О. Макарова «В защиту старых броненосцев и новых усовершенствований».

По ходу изложения хочется исправить одну досадную ошибку предшествующих исследователей заявленной темы. В упомянутых выше очерках Евгения Харитонова «Без войны они скучают» и Владислава Гончарова «Между Сциллой и Харибдой» указывается, что очерки «Наша будущая война» и «По поводу одного острова (Гадания о будущем)» в журнале «Исторический вестник» (1882 г.) опубликовал один и тот же человек Всеволод Крестовский. На самом деле, перу Крестовского принадлежит очерк «Наша будущая война», и описывается там военное столкновение с Германией, а не с Японией. Непосредственным поводом к написанию этого очерка явилось резонансное заявление генерала М.Д.Скобелева в защиту балканских народов от агрессивной политики Германии и Австро-Венгрии. Очерк «По поводу одного острова» о необходимости создания российской военно-морской базы на острове Цусима (sic!) принадлежит перу Евгения Ларионова.

Появление двух указанных очерков в соседних номерах журнала не было случайностью. В это время шла острая полемика между сторонниками двух направлений внешней политики Российской империи: «западного» и «восточного». Эта борьба, обостренная событиями Кульджинского кризиса 18791881 гг., когда в воды Дальнего Востока была послана русская эскадра, для которой требовалась постоянная незамерзающая база, послужила причиной для появления очерка Ларионова рядом с очерком Крестовского.

Анализируя перспективы войны с Германской империей, Всеволод Крестовский отметил, что подобная война со стороны Германии может быть только а) наступательной и б) молниеносной. Ибо в противном случае Германия рискует «предоставить ужасам войны свою собственную территорию» или, в случае затягивания войны, ее ждет

\footnotetext{
${ }^{8}$ Русское судоходство. 1886. № 2-9.

9 Роковая война 18 ?? года //Русское судоходство. 1887. № 20-21.
} 
экономическое банкротство. Поэтому России Всеволод Крестовский предлагает всеми силами затягивать войну: отступать, уклоняться от навязываемых немцами сражений, проводить на оставляемой территории тактику выжженной земли ( «Мы будем жечь все - и города, $u$ села, и нивы - все, начиная с достояния тех же немецких колонистов» (sic!)) и наполнять тыл немцев летучими отрядами казаков и башкир. В целом эти выкладки доказывают, что военные де6йствительно готовятся к прошлой войне: в общих чертах это тактика 1812 г.

Вторым писателем работающим жанре «грядущей войны» был военно-морской офицер (ушел в отставку в чине капитана 2-го ранга из-за злоупотреблений) Александр Конкевич. В 1886 г. он опубликовал в нескольких выпусках журнала «Русское судоходство» военно-утопический роман «Крейсер «Русская надежда»». Роман был посвящен актуальной в то время теме: возможным вариантам противостояния Великобритании, отношения с которой у России к 80-м гг. XIX в. были изрядно обострены. Сюжет поражал своим размахом: описания грандиозных морских баталий перемежались с описанием политических и военно-тактических интриг. Конкревич представил читающей публике впечатляющий проект подготовки России к морской войне против Британской империи.

В 1887 г. Александр Конкевич опубликовал новый военно-утопический роман «Роковая война 18?? года»- своеобразное продолжение предыдущего. Он изобразил грядущую морскую войну России против коалиции Италии, Турции и Австро-Венгрии. В процессе боевых действий русский флот пусть только на бумаге осуществляет давнюю русскую мечту и захватывает Босфор и Дарданеллы. В отместку итальянская эскадра высаживает морской десант... в районе Владивостока. Но в конце романа русская эскадра, посланная вокруг света из Кронштадта, громит супостатов.

Не прошел мимо разработки сценариев грядущей войны прославленный русский флотоводец, океанограф, вицеадмирал С.О.Макаров, одновременно теоретик судостроения и автор теории борьбы за живучесть корабля. В февра- ле и марте 1886 года он опубликовал в журнале «Морской сборник» свою работу «В защиту старых броненосцев и новых усовершенствований». В этом очерке Степан Макаров попытался использовать приемы художественной беллетристики для иллюстрации своих военно-технических идей. Для этого он подробно описал фантастическое сражение между эскадрами воображаемых «Синей» и «Белой» республик, расположенных автором ради удобства на островах Тихого океана, в котором побеждают «синие», использующие сверхсовременный броненосный флот, что делает их владыками морей.

Художественные достоинства всех вышеперечисленных произведений весьма слабые. Но их авторы - военные теоретики - выигрывают у профессиональных писателей-беллетристов точностью прогноза.

Всеволод Крестовский сумел предсказать фабулу будущей войны с Германией, пресловутый Der blitz Krieg; Евгений Ларионов указал на значение острова Цусима для доминирования военноморского флота в Желтом и Японском морях.

Отставной капитан Александр Канкревич использовал в романах свой богатый военно-морской опыт, чтобы проиллюстрировать новые приемы военноморской тактики. Евгений Харитонов в своем очерке делает вывод, что в отношении «тактических идей» этот автор во многом предвосхитил современную тактику ведения морских сражений. Да и совершенно фантастическое нападение итальянцев на Владивосток во втором романе отставного моряка служило вполне прагматической цели: подвигнуть правительство России на техническое перевооружение армии и флота (более конкретно - к началу строительства Транссибирской железной дороги).

О техническом переоснащении военного флота мечтал и адмирал Степан Осипович Макаров. Но ему было суждено погибнуть по описанному в собственном очерке сценарию: броненосец «Петропавловск» в точности повторил судьбу одного из кораблей, описанную в его фантастическом очерке (взрыв «букета мин» под днищем судна с последу- 
ющей детонацией артиллерийских погребов корабля)...

То есть указанные произведения можно рассматривать не как беллетристику, а как разновидность военно-теоретической литературы, своеобразный полигон для отработки новых идей и военных сценариев.

Издавались в России и чисто художественные фантастические произведения, где художественность вымысла писателя-беллетриста берет верх над прогностическими возможностями уже сложившегося жанра. Эти писатели «не отставали» от адмиралов и отставных офицеров, придумывая все новые и новые способы уничтожения себе подобных в будущих войнах, но способы чисто фантастические. Наступает эпоха «волшебных» изобретений, вытесняющих со страниц романов «устаревшие» пушки и пулемёты.

В начале $\mathrm{XX}$ в. интерес публики к грядущим морским сражениям резко упал. Теперь ставки делались на стремительно развивающуюся авиацию. В.С.Семенов, морской офицер, участник Цусимского сражения и небесталанный писатель, издал два романа о войне в воздухе (практически одновременно с романом Герберта Уэллса «Война в воздухе», что очень симптоматично). В первом романе «Царица мира» (1908) Владимир Семенов описывает гигантский воздушный аппарат, построенный гениальным русским инженером. Этот инженер - пацифист по своим убеждениям и желает навсегда покончить с войнами. Установив на «Царице мира» свое «волшебное» изобретение - аппарат, вызывающий детонацию всех типов взрывчатых веществ, он облетает планету и уничтожает все военные арсеналы. Но лишенное взрывчатки человечество не прекращает войн, а начинает воевать по старинке, холодным оружием. Мораль ясна - спасти человечество от самого себя невозможно. Во втором своём романе «Цари воздуха» (1908) Владимир Семенов изобразил ближайшее будущее, в котором Англия, изрядно опередив в самолетостроении другие державы, устанавливает воздушное господство над миром, правда, в конце концов, терпит поражение. Возможные аспекты при- менения авиации в военных действиях рассматривает в своей «аэрофантазии» «Гибель воздушного флота» (1911) и инженер Сергей Бекнев. В романе Павла Ордынского (Плохова) «Кровавый трон», описан могучий воздушный корабль, оснащенный «волшебным» изобретением - «лучами смерти», беззвучно поражающими аппараты врага ${ }^{10}$.

O неизбежности войны с Германией русские писатели-фантасты начали писать задолго до Балканского кризиса. Некоторые литераторы окрашивали надвигающуюся войну в розовые цвета «ура-патриотизма», когда русская армия может всё, а её враги - только то, что Россия им позволит. Романы Льва Жданова «Два миллиона в год», (1909); некоего Петра Р-цкого «Война «Кольца» с «Союзом»», (1913) или, например, «Конец войны. Последние дни мировой борьбы», (1915) рисовали неизбежную и легкую победу Антанты над Германией. Писатели поумнее и посерьёзнее понимали масштаб грядущей мировой катастрофы. Например, талантливый сибирский писатель А.С.Сорокин, написавший в 1909 г. повесть «Хохот Желтого Дьявола» (издана в 1914 г.). В отдельных деталях сибирский писатель угадал черты отдаленного будущего. К примеру, в его повести описаны «фабрики смерти» - удивительно точный прообраз фашистских концлагерей Второй мировой войны...

$$
* * *
$$

Революция 1917 года трактовалась юным советским обществом как прорыв в «абсолютное будущее». Декларация великого социального эксперимента и ощущение «молодости эпохи» вызвали появление в сценариях грядущих войн никогда не существовавшего в царской России социально-классового мотива. Грядущая война приобретала черты классового противостояния и очень часто декларировалась как пролог к грядущей мировой революции.

Одной из характерных черт жизни советского общества 1920-х гг. являлись

10 Харитонов E. «А без войны они скучают»// http://telegrafua.com/world/11848/ 
так называемые «военные тревоги». В историографии это определение прочно утвердилось за социально-политическим кризисом 1927 г., однако внимательное изучение современными историками (А. В. Голубев и другие ${ }^{11}$ ) общественных настроений на протяжении всего периода 1922-1929 годов доказывает, что «военные тревоги» возникали постоянно. Мир представлялся общественному сознанию юного советского общества короткой передышкой перед новой неизбежной войной. На протяжении всех 1920-х годов любое событие, происходившие на международной арене и как-то затрагивающее Советский Союз, воспринималось массовым сознанием, как признак надвигающейся ( войны. В подобных условиях романы о грядущей войне - «Гиперболоид инженера Гарина» Алексея Толстого, «Трест Д.Е.» Ильи Эренбурга, «Иприт» Всеволода Иванова и Виктора Шкловского, «Машина ужаса» (1925) и «Бунт атомов» (1928) Владимира Орловского, «Я жгу Париж» Бруно Ясенского, «Борьба в эфире», «Властилин мира»и «Продавец воздуха» Александра Беляева - находили широкий спрос у читающей публики.

Роман «Гиперболоид инженера Гарина», созданный Алексеем Толстым 12 является классическим произведением жанра «военно-утопического романа». Это утверждение может показаться моим читателям спорным, ведь в центре сюжета - отнюдь не война, а авантюра инженера Гарина, стремившегося к мировому господству через новое оружие.

\footnotetext{
${ }^{11}$ См.: Голубев A.B. «Если мир обрушится на нашу республику»: Советское общество и внешняя угроза в 1920-е-1940-е годы : [текст] / А.В.Голубев - М., 2008. С.88-131.: Он же. Советское общество и «военные тревоги» 1920-х годов // Отечественная история. - 2008. - № 1. - С.36-58.; Курдюкина M.M. Угроза войны глазами красноармейцев в 1920-е годы [текст] /М.М.Курдюкина // Война и мир в историческом процессе (XVII - XX в.) Ч.1. - Волгоград, 2003. - С.277-284.; Симонов H.C. «Крепить оборону страны Советов» : «Военная тревога» 1927 года и ее последствия // Отечественная история. - 1996. - № 3. - С.155-161.

${ }_{12}$ Толстой A.Н. Гиперболоид инженера Гарина : [роман] / А.Н. Толстой // Собрание сочинений, Том 4 - М., Художественная литература, 1958. $831 \mathrm{c}$.
}

Но, судя по первоначальной заявке 1924 г. Государственному издательству, Алексей Толстой планировал написать роман о великой европейской войне, спровоцированной действиями Гарина. Однако по мере написания замыслы менялись, Алексея Толстого все больше и больше занимала авантюра инженера Гарина, отодвигая мировую войну и революцию на второй план.

Но в своём романе «Гиперболоид инженера Гарина» Алексей Толстой использовал идеи и сюжетные ходы, которые широко применялись в последующих советских фантастических романах о грядущей войне.

1. Волшебное изобретение, дающее владельцу огромную власть. Одновременно - абсолютное оружие и универсальный инструмент.

2. Недобросовестный изобретатель (по совместительству - триксер, нарушитель всех и всяческих писанных и неписанных норм), угрожающий миру. По развитию сюжета оказывается не изобретателем, а профанатором, похитителем секрета изобретения у сумасшедшего профессора.

3. Сумасшедший профессор, оказывающийся подлинным автором всех идей, двигающих сюжет .

3. Герой, преследующий недобросовестного изобретателя - триксера. Вслед за триксером явился в роман Толстого прямо из русской волшебной сказки.

5. Маленький помощник героя. Родом также из волшебной сказки.

6. Сциентичность фантастики: подробное описание сущности «волшебного изобретения» и рабочая гипотеза строения Земли, обосновывающая основную интригу сюжета - борьбу за «оливиновый пояс»

7. Внутренний конфликт капиталистической системы - «пёс поедает псов» - приводящей и установлению мировой диктатуры одного человека.

8. Удар в слабую точку мировой капиталистической системы для начала всемирной революции: фактически Петр Гарин помог Шельге и другим коммунистам раскачать и обрушить мировую капиталистическую систему.

Эти сюжетные ходы в последствии использовались другими авторами в ро- 
манах о грядущей войне СССР с капиталистическим окружением. Рассмотрим некоторые из них.

Например, в романе «Иприт» Всеволода Иванова и Виктора Шкловского (1925 г.) испугавшиеся начавшейся в Индии и Китае революции империалисты развязывают против Советского Союза химическую войну, и вот город Ленинстрой (так в книге!) умирает прямо во время киносеанса под открытым небом, отряды Добролёта сражаются в небе с английской авиацией, на Москву падают радиоуправляемые снаряды, а английский коммунист, товарищ Роберт Нетлох взрывает вместе с собой высадившийся на Новой Земле английский десант. «Это воевали не люди, это воевали химические фабрики, и люди исполняли обязанности реактива на те или иные газы» ${ }^{13}$.

Для уничтожения противников «цивилизованного мира» империалистам нужно 1500 ооо тонн иприта. Это количество берется поставить профессор химии Монд, который накачивает своих рабочих специальным «бессонным» газом «сусанитом», чтобы они работали в три смены круглосуточно. По своим качествам «сусанит»- это типичное «волшебное» изобретение. А профессор Монд - профанатор, укравший идею «сусанита» у сумасшедшего надсмотрщика из Южной Африки, наблюдавшего за своими рабами и случайно открывшего свойства этого газа. Но у Советского Союза тоже есть «волшебные изобретения» - «целлюлоза инженера Ши», из которой делают расчески, самолеты и противогазы. А капиталистическому изобретателю-профанатору Монду противостоит советский триксер Павел Словохотов со своим ручным медведем Рокамболем. Он в силу врожденной безалаберности вляпывается в разные сомнительные истории, бежит от преследования советских граждан и милиции, которые принимают Словохотова то за жулика, то за немецкого шпиона, оказывается за границей, входит в доверие к профессору Монду, и совершает против Лондона дерзкую химическую

\footnotetext{
${ }^{13}$ Иванов, Вс., Шкловский, В. Иприт: [роман] / Всеволод Иванов, Виктор Шкловский. - Спб.: РЕдФИШ, ТИД «Амфора», 2005. - С.339.
}

диверсию: наполняет дома английской аристократии сонным газом. После чего лишенный сна английский пролетариат восстает против своих угнетателей.

Роман «Трест Д.Е. История уничтожения Европы» ${ }^{14}$ был написан Ильей Эренбургом в феврале-марте 1923 г. в Берлине, в том же году он вышел в издательстве «Геликон», затем - в Харькове и Москве. Это сатирический памфлет, повествующий об уничтожении Европы трестом, спонсированным крупнейшими американскими миллиардерами. Для осуществления своих планов американский трест использует фашистскую Францию, которая одну за другой уничтожает европейские страны, и напоследок гибнет сама. Во главе треста стоит Енс Боот, сын голландки и принца Монакского, человек без семьи и родины, побывавший артистом цирка, альфонсом, жиголо, солдатом Первой Мировой войны, краскомом Красной Армии, международным магнатом. Этот законченный авантюрист не находит себе места на земле, пока в голову ему не приходит идея уничтожить Европу. Заручившись поддержкой американских миллиардеров Джейбса, Хардайля и Твайвта, он разрабатывает план, который последовательно выполняет в жизнь.

В 1927 г. во Франции был опубликован фантастический памфлет бывшего помощника посла Французской республики в СССР Поля Морана «Я жгу Москву». Содержание романа вытекает из его названия: «цивилизованная» «свободная» Франция то ли должна сжечь (то ли уже сжигает) «коммунистическую Москву», как она сделала уже один раз в 1812 г. Это возмутило живущего во Франции польского эмигранта Бруно Ясенского, в то время - член Французской коммунистической партии. Всего за три месяца он пишет свой роман «Я жгу Париж», в котором описывает восстание пролетариата в городе Париже после объявления войны Советскому Союзу, борьбу с чумой и блокадой правительственных войск, наконец, призыв

\footnotetext{
${ }_{14}$ Эренбург И. Трест Д.Е. История гибели Европы [роман] / И. Эренбург // Собрание сочинений в девяти томах. - Т.1 - М., художественная литература, 1962. -534 c.
} 
Парижа к восстанию всего европейского пролетариата ${ }^{15}$. Роман был напечатан несколькими выпусками в 1928 г. в газете «Юманите», что привело к высылке Бруно Ясенского из Франции. С 1929 г. он жил и работал в СССР, написал несколько повестей и роман «Человек меняет кожу» о сооружении большого оросительного канала в Таджикистане, об английских шпионах, недобитых басмачах и бдительных чекистах. По иронии судьбы именно «бдительные чекисты» поставили точку в творчестве Бруно Ясенского, арестовав и расстреляв его по доносу в 1937 г.

Какие же характерные приметы времени прочитываются в рассмотренных романах?

1. Война в романах 1920-х гг. приобретает черты социального противостояния: фронт будет проходить не только по географическим границам государств, но и внутри общества. Против нас будут все богатые, за нас будут все бедные и угнетенные. Декларируется победа Советского Союза не за счет лучшей военной техники, а за счет превосходства социального строя и поддержки мирового пролетариата. Дело неизменно заканчивается Мировой Социалистической революцией.

2. Поражает научно-просветительский энтузиазм рассмотренных произведений, которые постулируют мистическую роль науки в юном советском обществе; обожествление науки и техники как один из важнейших принципов мироощущения людей Коммуны

3. Герои писателей обладают огромной индивидуальной свободой и ничем не ограниченной инициативой. Главные персонажи рассмотренных произведений - Петр Гарин, Павел Словохотов, Енс Боот - триксеры, нарушители всех и всяческих норм и установлений. Триксер постулирует абсолютную внутреннюю свободу, что было созвучно самой эпохе, эпохи свободы, эпохе поисков, многочисленных социальных экспериментов. Показательно, что два известных всей стране литературных персонажа, появившихся в рассматри-

${ }_{15}$ Ясенский Б. Я жгу Париж [роман] / Б. Ясенский - Курск, Курское книжное изд-во, 1963. - 303 с. ваемую эпоху - Остап Бендер и Буратино - тоже триксеры. Но не только триксеры были характерными героями эпохи. Революция разбудила широкую инициативу людей, что отражала современная событиям литература. По своей личной инициативе преследует Гарина Шельга: "Даю слово коммуниста - убить вас при первой возможности , Гарин... Даю слово отнять у вас аппарат и привезти его в Москву...» По своей личной инициативе водолив Сарнов и китаец Син-Бин-У из романа «Иприт» становятся сыщиками, преследующими Павла Словохотова, которого они приняли за немецкого шпиона Кюрре. По своей личной инициативе китаец Чуг из «Треста Д.Е.» поднимает разбитых красноармейцев в контрнаступление на панскую Польшу: "Товарищи, ворочай оглобли. Идем бить их! Мать!.. Даешь Eвpony!» Их никто не уполномочивал.

В этом и заключено главное противоречие эпохи - героев рассмотренных произведений никто не уполномочивал. Ни Совнарком, ни ЦК ВКП(б), ни ГПУ. А в конце 1920-х - начале 1930-х гг. перечисленные учреждения все сильнее накладывали свою руку как на личную, так и на общественную инициативу. И вот уже Всеволод Иванов и Виктор Шкловский сами разрушают построенный собственными руками мир в последней главе своего романа, сводя его к безответственным россказням сельского чудака Павла Словохотова. Они будто бы сами испугались своей выдумки, и поспешили её дезавуировать. Может быть, в этом и состоит главная неудача романа «Иприт» - что писатели испугались Системы, которая уже дышала им в затылок. Хотя заключительная сцена должна была рождать еще больше вопросов к авторам со стороны Системы, ибо превращает весь роман в горячечный бред отравленного ипритом человека. Отравленного, надо понимать, в грядущей войне...

$$
* * *
$$

1929 год принято называть «годом Великого перелома». И именно в это время появляются переходные научно-фантастические произведения, где 
идея грядущей войны как социального противостояния сменяется идеей войны как противостояния технологий. В качестве примера можно привести рассказы Сергея Беляева «Истребитель 17Y» (1928), (переработан в последствии в роман «Истребитель 2-Z»), Виктора Левашова «Танк смерти» (1928), Михаила Ковлева «Капкан самолетов» (1930), повесть Анатолия Скачко «Может быть, завтра...» (1930) ${ }^{16}$. В этих рассказах и повестях появляются сверхсовременные и неуязвимые самолеты, сверхпроходимые танки, зенитные орудия, стреляющие на звук, многомоторные самолеты и дирижабли.

Чтобы наглядно представить разницу между «военно-утопическим романом» образца 20-х гг. и образца 30-х гг., достаточно рассмотреть различия двух произведений писателей-однофамильцев: научно-фантастического романа «Радиомозг» Сергея Беляева (1928) ${ }^{17}$, и романа «Властелин мира» Александра Беляева (1929) ${ }^{18}$.

Сюжет обоих романов весьма схож. В руках безнравственных людей оказывается «волшебное» изобретение, позволяющее им читать и записывать мысли людей, а также излучать безотказные мысленные приказания. Этими маньяками овладевает идея мирового господства. Они начинают действовать. Все мировое сообщество ищет защиту от нового оружия. Им оказывается аналогичное изобретение нашего соотечественника, и претенденты на мировое господство оказываются побежденными.

Более любопытны различия сюжета романов.

В романе Сергея Беляева на сцену выведены социальные силы, и конфликт вокруг «радиомозга» приобретает характерный для 20-х гг. социально-классовый мотив. Советский инженер-изобретатель Тах в борьбе против братьев Гричаров опирается на мощь всего советского государства: поддержку Совнаркома, ЦК ВКП(б), энтузиазм рабочего

\footnotetext{
${ }^{16}$ Гончаров В. Указ. Соч. С.528.

${ }^{17}$ Беляев С.М. Радиомозг. М.-Л.: Мол. гвардия, 1928. $180 \mathrm{c}$.

${ }^{18}$ Беляев А.Р. Властелин мира // Собрание сочинений, т.4 - М.: Молодая гвардия, 1963.
}

коллектива завода «Красный химик». У Александра Беляева война будущего показана как война технологий. Классового врага сменил недобросовестный изобретатель Штирнер, который, кстати сказать, и не собирался нападать на CCCP. Советский инженер Качинский боролся с ним по собственной инициативе после просьбы, озвученной частными лицами.

Начиная с этого времени, в сюжетах будущей войны тема социального противостояния сменяется темой технического противостояния; борьба изобретательских умов и война моторов сменяет романтику грядущей мировой революции. Это изменение в литературе коррелирует с изменением государственной политики в стране, с принятым Сталиным курсом на форсированную индустриализацию. Надежды на скорую мировую революцию у советского руководства развеялись окончательно. Если до этого фантастика побеждала врага за счет преимуществ социального строя, то теперь она была призвана побеждать врагов за счет лучшей техники. Однако мотив классовой войны никуда не ушел. Он изменился: фантастические произведения 30-х гг. утверждают, что преимущества социального строя обеспечат Советскому Союзу научный и технический приоритет над капиталистическим окружением. Кроме того, мотив «мирового пожара» пережил короткий ренессанс перед самой Великой Отечественной войной, в 1938-1940 гг.

$$
* * *
$$

Абсолютное техническое превосходство Советского Союза перед врагами в будущей войне описали: Владимир Киршон в спектакле «Большой день», Петр Павленко в романе «На Востоке», Николай Шпанов в романе «Первый удар», Георгий Байдуков в повестях «Разгром фашистской эскадры» и «Последний прорыв», Сергей Беляев произведении «Истребитель 2-Z» и многие другие советские писатели довоенного периода. По мнению Владислава Гончарова, в 30-е гг. романы о грядущей войне были отделены от остальной «несерьезной» 
фантастики в самостоятельный жанр, имеющий важное пропагандистское значение ${ }^{19}$. Главными врагами Советского Союза в этих романах выступали Япония на востоке и Германия на западе. Второстепенным врагом - Польша.

В романе Петра Павленко «На Востоке», вышедшем в 1937 г., описан сценарий нападения Японии на СССР. В середине 30-х гг. именно Япония считалась (и как показали Хасан и Халхин-Гол - небезосновательно) наиболее вероятным противником в будущей войне. В романе японские войска атакуют советские рубежи на советско-маньчжурской границе, и неожиданно для себя натыкаются на хорошо подготовленную оборону. Против наступающих самураев используются все виды оружия, включая фантастические подземные электрические установки. Когда самураи выдыхаются, из подземных казематов выезжают советские танки и добивают врага. Центральной сценой романа становится речь Сталина на срочно созванном партийном съезде в Большом театре. Своей мистической силой эта речь меняет ход войны, вдохновляет бойцов в подземных казематах и ведет красноармейцев в решающее наступление.

Пьеса Владимира Киршона «Большой день» моложе романа Павленко на один год. Она была поставлена в нескольких театрах как «оборонная пьеса», но быстро исчезла из репертуара, поскольку Владимир Киршон 1937 гг. был арестован в числе наиболее ортодоксальных коммунистических литераторов, обвинен в принадлежности к "троцкистской группе в литературе» и расстрелян как «враг народа».

В пьесе Киршона воспроизведены первые два дня войны. После нанесения по CCCP первого и неудачного удара немцы переходят к обороне на созданном заранее невиданном заградительном рубеже. Однако десантники майора Петра Кожина преодолевают его. Призванные в нацистскую армию рабочие - бывшие «красные фронтовики» переходят на сторону десантников Кожина. Начинается широкое наступление советских танков и авиации: «Mы наступаем,

\footnotetext{
${ }^{19}$ Гончаров В. Указ. Соч. - С.528.
}

наступает Большой день!». Начинается восстание в самой Германии. Десантники получают новое задание - поддержать восстание, лететь в Германию, где каждому из них предстоит стать командиром отряда восставших рабочих.

В романе Николая Шпанова описаны первые двенадцать часов грядущей войны. Нападение Германии на СССР вызывает исключительный порыв патриотизма в советском народе. На Красной площади начинаются демонстрации добровольцев, требующих записать их в Красную Армию. Но Советская страна обходится силами своей кадровой армии. Все планы немцев срываются один за другим по логике исторической закономерности. Победу обеспечивает абсолютное превосходство Советского Союза в технике. Чего стоит только единственный в мире «волшебный» бомбардировщик с небывалым диапазоном скоростей. Ценой жизни двух летчиков уничтожена целая система подземных аэродромов фашистов. Германский пролетариат Гамбурга, превращенный фашистами в рабов, под бомбами советской авиации поёт Интернационал. Такой вот розовый ура-патриотизм образца 1930-х годов.

На примере рассматриваемых произведений можно увидеть следующие изменения в сюжетной линии грядущей войны в отечественной литературе: 1) Декларируется, что преимущества социального строя дают СССР абсолютное технологичное превосходство перед противниками; 2) В этих условиях первый удар империалистов, страшный и кровавый в сценариях 20х годов, превращается в фарс, в «попытку с заранее негодными средствами»; 3) Красная Армия переходит в наступление; это наступление провоцирует начало пролетарского восстания в Европе и Азии.

Апофеозом описанного сюжета стал кинофильм «Если завтра война», созданный в 1938 г. коллективом режиссеров под руководством Ефима Дзигана на основе кинохроники, снятой во время маневров Красной Армии.

Какие особенности разобранных литературных произведений бросаются в 
глаза, кроме общей неправдоподобности сценариев и фантастических ТTX используемой Красной Армии техники? Это, прежде всего, утверждение предпочтительности советского наступления перед обороной. Именно подобная предпочтительность и порождала фантастическую военную технику и неправдоподобный сценарий, в котором иностранная интервенция отражается буквально в течение нескольких часов.

Сюжеты литературных произведений свидетельствуют также о том, что сталинское руководство по-прежнему готовилось к революционно-классовой войне. Оно надеялось превратить войну против СССР в борьбу против фашизма и капитализма внутри империалистических держав.

Фантастика в предвоенном СССР выполняла важнейшую функцию мобилизации общественного сознания накануне войны. А так как весь предвоенный период мыслился руководством страны и большей частью общества как «канун войны», то сценарии грядущей войны появлялись в фантастической литератуpe постоянно. И эта пропаганда сыграла свою роль: общественное сознание советского общества перестало бояться грядущей войны, её стали с нетерпением ждать:
«И все же мы дойдем до Ганга

И мы еще умрем в боях,

Чтоб от Японии до Англии

Сияла Родина моя!»

Конечно, не одна литература сыграла в этом свою роль, но вся система социальных и культурных преобразований, осуществленных в Советской стране и получивших название «Культурная революция» и «Великий перелом». Но литература играла в этих процессах очень важную роль.

PostSkriptum. Когда статья была уже написана и подписана в печать, автору стало известно, что власти Румынии стали говорить о возможности присоединения территорий Черновицкой и даже Одесской областей ставшей резко недееспособной Украины. В этих условиях в Румынии возродился интерес к изданному в 2012 г. военно-утопическому роману «Кровь на Днестре» румынского писателя Кристиана Негря. Роман описывает войну Украины и стоящей за ее спиной России с коалицией в составе Румынии, Венгрии, Болгарии и Турции. Война должна начаться в 2014 г. (sic!) после осуществленного в Киеве государственного переворота (sic!) и попытки захвата Украиной Кишинёва, на что её конечно же спровоцировала Россия. Так что тема грядущих войн не исчерпана ни у нас, ни на Западе.

\section{Список литературы:}

1. Беляев С. М. Радиомозг : [роман] / Сергей Беляев М.-Л.: Молодая гвардия, 1928.

2. Беляев А. Р. Властелин мира : [роман] / Александр Беляев // Собрание сочинений, т. 4 - М.: Молодая гвардия, 1963.

3. Голубев А. В. «Если мир обрушится на нашу республику»: Советское общество и внешняя угроза в 1920-е - 1940-е годы : [текст] / А.В.Голубев - М., 2008. С.88-131.

4. Голубев А. В. Советское общество и «военные тревоги» $1920-$ х годов : [текст] / А. В. Голубев // Отечественная история. - 2008.-№ 1. С.36-58.

5. Гончаров В. Между Сциллой и Харибдой // В кн.: Анисимов С. В. Вариант «Бис». М.: АСТ, Ермак, 2003.

6. Иванов Вс., Шкловский В. Иприт: [роман] / Всеволод Иванов, Виктор Шкловский. - Спб.: РЕдФИШ, ТИД «Амфора», 2005.

7. Канкревич А. Крейсер «Русская надежда» [роман] / Александр Канкревич // Русское судоходство. 1886. № 2-9.

8. Канкревич А. Роковая война 18?? года [роман] / Александр Канкревич //Русское судоходство. 1887. № 20-21.

9. Крестовский В.В. Наша будущая война : [текст] / Всеволод Крестовский // Исторический вестник. Историко-литературный журнал. Т.8. С-Пб, Тип. А. С. Суворина, 1882. C.157-167. 
10. Курдюкина М. М. Угроза войны глазами красноармейцев в 1920-е годы [текст] / М. М. Курдюкина // Война и мир в историческом процессе (XVII - XX в.) Ч.1. - Волгоград, 2003. - С.277-284.

11. Кулешова Н. Ю. «Большой день»: грядущая война в литературе 1930-х годов [текст] / Н. Ю. Кулешова // Отечественная история. -2002. № 1. - С.181-191.

12. Ларионов Е. В. По поводу одного острова (Гадание о будущем) [текст] / Евгений Ларионов // Исторический вестник. Историко-литературный журнал. Т.9. С-Пб, Тип. А. С.Суворина, 1882 С.129-163.

13. Прашкевич Г. М. Шпион в Юрском периоде: Сб / Геннадий Прашкевич, М.: АСТ, 2003.

14. Прашкевич Г. М. Адское пламя. / Геннадий Прашкевич Новосибирск, Свиньин и сыновья, 2007. - 196 с.

15. Симонов Н. С. «Крепить оборону страны Советов»: «Военная тревога» 1927 года и ее последствия [текст] / Н.С. Симонов // Отечественная история. - 1996.-№ 3. - C.155-161.

16. Толстой А. Н. Гиперболоид инженера Гарина : [роман] / Алексей Толстой // Собрание сочинений, Том 4 - М., Художественная литература, 1958.

17. Харитонов Е. В. «Без войны они скучают» // http://telegrafua.com/world/11848/print/\$

18. Харитонов Е. В. Взгляд на фантастику // http://litforum.ru/lofiversion/index.php/t24348.html (последнее посещение - 25 марта 2012 г.)

19. Эренбург И. Г. Трест Д.Е. История гибели Европы : [роман] / Илья Эренбург // Собрание сочинений в девяти томах. - Т.1 - М., художественная литература, 1962.

20. Ясенский Б. Я жгу Париж : [роман] / Бруно Ясенский - Курск, Курское книжное изд-во, 1963.

\section{References (transliteration):}

1. Belyaev S. M. Radiomozg : [roman] / Sergei Belyaev M.-L.: Molodaya gvardiya, 1928.

2. Belyaev A. R. Vlastelin mira : [roman] / Aleksandr Belyaev // Sobranie sochinenii, t.4 M.: Molodaya gvardiya, 1963 .

3. Golubev A. V. «Esli mir obrushitsya na nashu respubliku»: Sovetskoe obshchestvo i vneshnyaya ugroza v 1920-e - 1940-e gody : [tekst] / A.V.Golubev - M., 2008. S.88-131.

4. Golubev A. V. Sovetskoe obshchestvo i «voennye trevogi» 1920-kh godov : [tekst] / A. V. Golubev // Otechestvennaya istoriya. - 2008.-№ 1. S.36-58.

5. Goncharov V. Mezhdu Stsilloi i Kharibdoi // V kn.: Anisimov S. V. Variant «Bis». M.: AST, Ermak, 2003.

6. Ivanov Vs., Shklovskii V. Iprit: [roman] / Vsevolod Ivanov, Viktor Shklovskii. - Spb.: REdFISh, TID «Amfora», 2005.

7. Kankrevich A. Kreiser «Russkaya nadezhda» [roman] / Aleksandr Kankrevich // Russkoe sudokhodstvo. 1886. № 2-9.

8. Kankrevich A. Rokovaya voina 18?? goda [roman] / Aleksandr Kankrevich //Russkoe sudokhodstvo. 1887. № 20-21.

9. Krestovskii V.V. Nasha budushchaya voina : [tekst] / Vsevolod Krestovskii // Istoricheskii vestnik. Istoriko-literaturnyi zhurnal. T.8. S-Pb, Tip. A. S. Suvorina, 1882. S.157-167.

10. Kurdyukina M. M. Ugroza voiny glazami krasnoarmeitsevv1920-e gody [tekst] / M. M. Kurdyukina // Voina i mir v istoricheskom protsesse (XVII - XX v.) Ch.1. - Volgograd, 2003. - S.277-284.

11. Kuleshova N. Yu. «Bol'shoi den'»: gryadushchaya voina v literature 1930-kh godov [tekst] / N. Yu. Kuleshova // Otechestvennaya istoriya. -2002. № 1. - S.181-191.

12. Larionov E. V. Po povodu odnogo ostrova (Gadanie o budushchem) [tekst] / Evgenii Larionov // Istoricheskii vestnik. Istoriko-literaturnyi zhurnal. T.9. S-Pb, Tip. A. S.Suvorina, 1882 S.129-163.

13. Prashkevich G. M. Shpion v Yurskom periode: Sb / Gennadii Prashkevich, M.: AST, 2003.

14. Prashkevich G. M. Adskoe plamya. / Gennadii Prashkevich Novosibirsk, Svin'in i synov'ya, 2007. - $196 \mathrm{~s}$. 


\section{Культура и искусство 6(18) • 2013}

15. Simonov N. S. «Krepit' oboronu strany Sovetov» : «Voennaya trevoga» 1927 goda i ee posledstviya [tekst] / N.S. Simonov // Otechestvennaya istoriya. - 1996. - № 3. S.155-161.

16. Tolstoi A. N. Giperboloid inzhenera Garina : [roman] / Aleksei Tolstoi // Sobranie sochinenii, Tom 4 - M., Khudozhestvennaya literatura, 1958.

17. Kharitonov E. V. «Bez voiny oni skuchayut» // http://telegrafua.com/world/11848/print/\$

18. Kharitonov E. V. Vzglyad na fantastiku // http://litforum.ru/lofiversion/index.php/t24348.html (poslednee poseshchenie - 25 marta $2012 \mathrm{~g}$.)

19. Erenburg I. G. Trest D.E. Istoriya gibeli Evropy : [roman] / Il'ya Erenburg // Sobranie sochinenii v devyati tomakh. - T.1 - M., khudozhestvennaya literatura, 1962.

20. Yasenskii B. Ya zhgu Parizh : [roman] / Bruno Yasenskii - Kursk, Kurskoe knizhnoe izd-vo, 1963 . 